\title{
PERUBAHAN MASYARAKAT DAN PERUBAHAN TUNTUTAN TERHADAP PENDIDIKAN
}

\author{
Muhajir \\ INSTITUT AGAMA ISLAM NEGERI (IAIN) METRO \\ Jalan Ki Hajar Dewantara 15 A Iring Mulyo Kota Metro
}

\begin{abstract}
ABSTRAK
Masyarakat Indonesia sekarang berada dalam suatu era yang disebut era reformasi, di era reformasi lahir grassroot revolusi sosial yang merupakan suatu korelasi nilai-nilai budaya yang ingin mewujudkan suatu masyarakat yang demokratis. Perubahan kondisi masyarakat saat ini dengan runtuhnya rezim orde baru telah melahirkan suatu visi yang baru mengenai kehidupan masyarakat yang lebih sejahtera yaitu adanya pengakuan HAM. Pendidikan nasional juga ikut terseok-seok dilanda krisis dan berbagai permasalahan yang terjadi di dunia pendidikan. Perubahan tuntutan terhadap pendidikan bersifat dinamis, fleksibel sehingga dapat menyerap perubahan-perubahan yang cepat perkembangan ilmu dan teknologi dengan memperhitungkan kendala-kendala pendidikan nasional yaitu sangat sentraistik, birokratis dan matinya inovasi. Lahirnya suatu generasi baru "The Net-Generation" (generasi internet) harus disikapi dengan positif, sehingga masyarakat generasi ini dapat berkembang dengan optimal kemampuannya yang mengarah pada kemajuan bangsa dan negara Indonesia. Profesionalitas guru harus ditingkat kompetensinya dengan penguasaan TI (Teknologi Informasi) sehingga guru tidak GATEK (Gagap Teknologi) tetapi harus dapat menggunakan teknologi dalam mendukung proses pembelajaran.
\end{abstract}

Kata Kunci: Perubahan Masyarakat, Perubahan Tuntutan, Pendidikan

\section{A. Latar belakang masalah}

Masyarakat dan bangsa Indonesia kini berada di dalam suatu era baru yaitu era reformasi. Di dalam masa transisi menuju suatu masyarakat baru yang demokratis telah melahirkan suatu euforia yang dapat bermuara kepada disintegrasi bangsa, terlepasnya pengendalian diri karena lepasnya kungkungan yang telah membatasi kemerdekaan seseorang. Dilihat dari segi itu maka krisis yang terjadi dewasa ini merupakan suatu krisis kebudayaan. Dilihat dari segi ekonomi, gerakan reformasi menunjukkan lahirnya suatu kekuatan ekonomi baru yang meninggalkan paradigma ekonomi konglomerasi Orde Baru sehingga mengakibatkan perubahan sosial seperti yang di definisikan Selo Soemardjan dalam Soejono Soekanto (1982:337), "segala perubahan-perubahan pada lembaga-lembaga kemasyarakatan di dalam suatu masyarakat yang mempengaruhi sistem sosial termasuk di dalamnya nilai-nilai, sikap dan pola perilaku diantara kelompok-kelompok dalam masyarakat". 
Di mana-mana telah mulai lahir grass-root revolusi sosial dan ekonomi, revolusi tersebut merupakan suatu revolusi nilai-nilai budaya. Jelaslah kiranya apabila kita ingin mewujudkan nilai-nilai era reformasi yaitu suatu masyarakat yang demokratis atau suatu masyarakat madani maka pertanyaan yang muncul pada kita ialah : apa peran pendidikan nasional dalam menata kembali kehidupan masyarakat dan bangsa Indonesia, termasuk gejala disintegrasi bangsa yang muncul di berbagai nusantara ? lahirnya masyarakat Indonesia baru dengan nilai-nilai yang baru, begitu pula untuk menata kembali nilai-nilai sebagai ekses dari eforia demokrasi pasca Orde Baru diperlukan suatu peninjauan kembali dan penataan kembali penyelenggaraan pendidikan nasional berdasarkan paradigma baru.

Pendidikan nasional terseok-seok dilanda krisis. Mungkin pula krisis itu sendiri disebabkan karena kualitas output pendidikan nasional itu sendiri, bahkan akhir-akhir ini banyak timbul masalah dari mulai ijazah asli tapi palsu (ASPAL), antara senang dan kecurigaan terhadap dana Bantuan Operasional Sekolah (BOS), sampai pro kontra rancangan UU Guru dan Dosen yang masih jadi perdebatan hangat, juga tidak lepas dari mahalnya biaya pendidikan yang dirasakan oleh masyarakat samapai-sampai ada kasus siswa yang gantung diri karena malu tidak dapat bayar uang sekolah, juga kita dikejutkan dengan banyaknya siswa yang putus sekolah tahun 2004, SD/MI : 650.000, SMP/MTs : 100.000, SMA/MA/SMK : 45.000 (Kompas, 10/10/05).

Sistem pendidikan nasional yang ideal adalah sistem pendidikan yang mampu memelihara dan mengembangkan kebudayaan, hal ini berarti bahwa sistem pendidikan, khususnya sistem sekolah berisi unsur-unsur vital bagi kelestarian dan pengembangan kebudayaan krisis yang menimpa pendidikan nasional bukan hanya semata-mata karena krisis dana tetapi mungkin pula karena kekaburan arah dan kehilangan kemudi. Seperti yang dikemukakan oleh Wayan Ardhana W (1997:1), yang menyatakan bahwa pendidikan kita sekarang ini juga dilanda oleh arus mediokritas yang antara lain : (1) siswa yang sudah puas dengan sekedar nilai lulus, (2) guru yang mengajar asal-asalan, (3) orang tua yang bersedia membeli nilai NEM, lebih lanjut Wayan Ardhana mengemukakan beberapa tantangan yang akan dihadapi dalam abad 21 yaitu perdagangan, industri, efisiensi/efektivitas (pengelolaan) dan kreativitas. Oleh karena diperlukan sumber daya manusia yang berkualitas yang berorientasi pada Achievement (prestasi kerja) dan yang berorientasi pada rasionalitas.

Sistem pendidikan nasional yang ideal adalah sistem pendidikan yang mampu memelihara dan mengembangkan kebudayaan, hal ini berarti bahwa sistem pendidikan, khususnya sistem sekolah berisi unsur-unsur vital bagi kelestarian dan pengembangan kebudayaan (Dimyati, 1988:159), Indonesia di ibaratkan kapal bisa karam apabila sumber daya manusianya berseteru dan berkelahi satu dengan yang lain, oleh sebab itu pembenahan pendidikan nasional merupakan syarat mutlak untuk membenahi kehidupan masyarakat dan bangsa Indonesia yang ditimpa krisis yang berkepanjangan, mulai dari naiknya 
tarif bahan bakar minyak (BBM) yang sangat mempengaruhi sendi-sendi kehidupan masyarakat.

\section{B. PEMBAHASAN :}

\section{Perubahan Masyarakat Saat Ini}

Perubahan sosial serta gejolak sosial politik ekonomi yang terjadi akhirakhir ini menunjukkan betapa pentingnya pengembangan pribadi bagi seorang warga Indonesia yang berwatak dan bertaqwa. Sikap hidup ini tentunya bertentangan dengan sikap hidup yang penuh kekerasan yang tampak dewasa ini. Bangsa Indonesia seakan -akan tidak mampu hidup bersama di dalam perbedaan. Toleransi menghilang, padahal sikap toleransi dan mau hidup bersama merupakan perekat dari bangsa dan negara Indonesia. Pendidikan bersama yang merupakan perekat dari bangsa dan Negara Indonesia. Pendidikan di masa lalu rupa-rupanya telah gagal untuk menghidupkan sikap yang mulia ini. Selanjutnya, agenda reformasi yang kita perjuangkan ialah lahirnya suatu masyarakat Indonesia yang demokratis, yang hidup damai antara annggotanya serta menciptakan suatu masyarakat dan mempersiapkan manusia Indonesia di dalam kehidupan global dengan mempunyai daya saing yang tinggi.

Rontoknya nilai-nilai otokrasi Orde Baru telah melahirkan suatu visi yang baru mengenai kehidupan masyarakat yang lebih sejahtera ialah pengakuan terhadap hak-hak asasi manusia, hak politik dan hak asasi masyarakat. kita ingin membangun suatu masyarakat baru yaitu masyarakat demokrasi yang mengakui akan kebebasan individu yang bertanggung jawab. Pada masa orde baru hak-hak individu telah dirampas oleh pemerintah. Keadaan ini telah melahirkan suatu pemerintah yang terpusat dan otoriter, sehingga tidak mengakui akan hak-hak daerah. Kekayaan nasional, kekayaan daerah telah dieksploitasi untuk kepentingan segelintir elite politik dan ekonomi di pusat. Keadaan yang terjadi berpuluh-puluh tahun tersebut telah melahirkan suatu rasa curiga dan sikap tidak percaya kepada pemerintah. Lahirlah gerakan-gerakan saparatisme yang ingin memisahkan daerahnya dari Negara Kesatuan Republik Indonesia. Oleh sebab itu, desentralisasi atau otonomi daerah telah merupakan salah satu tuntutan era reformasi.

Menurut Tilaar (2002:2) ciri-ciri kehidupan dunia abad 21 berdasarkan para pakar futurolog dalam skenario kehidupan dunia abad 21, mengidentifikasi ada 4 macam ciri utama yaitu :

\section{a. Dunia Tanpa Batas (Borderless World)}

Dengan adanya kemajuan ilmu pengetahuan dan teknologi terutama teknologi informasi maka sekat-sekat kehidupan manusia menjadi sirna. Dunia seakan-akan menjadi satu. Dunia menjadi suatu tempat yang disebut suatu placeless society. Dengan demikian komunikasi antara-manusia, hubungan antara manusia, masyarakat dan bangsa menjadi transparan. Tidak ada lagi yang dapat ditutup-tutupi. Umat manusia telah menjadi satu. Perdagangan dunia, ekonomi dunia tidak lagi dibatasi lagi oleh perusahaan- 
perusahaan domestik tetapi juga oleh perusahaan multi-nasional yang tanpa mengenal negara. Dunia yang terbuka juga menuntut suatu bentuk masyarakat baru yaitu masyarakat terbuka, masyarakat yang demokratis.

b. Kemajuan Ilmu Pengetahuan dan Teknologi dan Aplikasinya di Dalam Kehidupan Manusia

Kemajuan ilmu dan teknologi yang begitu pesat sehingga dunia membentuk suatu masyarakat baru ialah masyarakat ilmu pengetahuan atau knowledge society. Teknologi komunikasi telah menolong penyebaran ilmu pengetahuan dan selanjutnya pengembangan serta pemanfaatannya untuk peningkatan mutu kehidupan manusia. Selanjutnya, kemajuan teknologi komunikasi telah membantu umat manusia untuk mengenal ilmu pengetahuan dengan lebih mudah, lebih cepat, lebih banyak, lebih up-todate.

c. Kesadaran Terhadap Hak dan Kewajiban Asasi Manusia (Human Rights and Obligations)

Rontoknya ideologi komunis serta ideologi otoriter lainnya telah menonjolkan nilai-nilai kemanusiaan dan hakikat manusia sebagai sesuatu yang harus dihormati. Hak-hak manusia dimanapun di dunia ini adalah sama yaitu hak untuk hidup dan hak untuk dihidupi. Sejalan dengan itu pula, setiap manusia wajib mempunyai tanggung jawab untuk memelihara masyarakat yang bebas dari ketakutan, bebas dari paksaan dan bebas untuk mewujudkan hakikat hidupnya sendiri dengan memperhatikan kepentingan hidup bersama.

d. Kerjasama dan Kompetisi antar bangsa (Mega Competition Society)

Masyarakat yang terbuka yang tanpa batas memungkinkan kerjasama antar masyarakat dan antar bangsa. Satu bangsa tidak dapat hidup terisolasi tanpa kerjasama dengan bangsa yang lain. Dan di dalam hidup bersama yang memberikan kesempatan yang sama kepada setiap individu, setiap kelompok, maka akan terjadi kompetisi yang sehat antar masyarakat, antarbangsa. Dengan demikian, manusia abad 21 mempunyai kesempatan untuk berkembang sepenuhnya sesuai dengan potensi yang ada padanya. Kesempatan untuk berkembang akan memungkinkan seorang atau sekelompok masyarakat atau bangsa untuk berbuat sesuatu yang terbaik bagi dirinya, bagi masyarakatnya dan bagi umat manusia. Dengan kompetisi yang terbuka dan sehat ini maka taraf hidup manusia diharapkan akan semakin meningkat.

\section{Perubahan tuntutan terhadap pendidikan?}

Sistem pendidikan nasional sebagai suatu organisasi haruslah bersifat dinamis, fleksibel, sehingga dapat menyerap perubahan-perubahan yang cepat antara lain karena perkembangan ilmu dan teknologi, perubahan masyarakat menuju kepada masyarakat yang semakin demokratis dan menghormati hak-hak asasi manusia. Dengan memperhitungkan kendala-kendala yang kita hadapi 
dalam pelaksanaan pendidikan nasional yaitu suatu sistem yang sangat sentralistis, birokratis dan matinya inovasi, Tilaar (2002:6) mengusulkan beberapa kebijakan reformasi manajemen pendidikan nasional :

a. Desentralisasi Pengelolaan Pendidikan Nasional

Suatu sistem pengelolaan sistem pendidikan nasional yang sentralistis tidak memungkinkan lahirnya suatu masyarakat terbuka yang demiokratis atau terwujudnya masyarakat madani abad 21, dimana setiap manusia mempunyai kesempatan untuk mengembangkan potensinya dan menyumbangkan untuknya untuk sebesar-besarnya bagi kesejahteaan masyarakat. Pelaksanaan desentralisasi sistem pendidikan nasional berarti memberikan keleluasaan yang besar kepada pemerintah daserah dan hal ini sesuai dengan kebijakan nasional untuk melaksanakan otonomi daaerah bahkan sampai ke daerah. Reformasi politik meminta reformasi pendidikan karena dengan demikian partisipasi langsung dari rakyat dalam bidang politik, ekonomi, hukum akan dapat terlaksana.

b. Pendidikan Dasar Sebagai Basis Pengembangan Sumber Daya Manusia

Dewasa ini pelaksanaan pendidikan dasar kita telah masuk dalam perangkap dualisme atau rebutan kekuasaan antara pemerintah pusat dan pemerintah daerah. Kericuhan pengelolaan tersebut tentunya akan menghasilkan kualitas pendidikan yang rendah dan menghambat pelaksanaan wajib belajar 9 tahun. Bukankah pemerintah daerah yang lebih mengetahui anak siapa dan dimana terdapat anak-anak yang bersekolah dan tidak bersekolah ? Oleh sebab itu, sudah pada waktunya untuk menyerahkan pengelolaan pendidikan dasar seutuhnya kepada pemerintah daerah.

Apabila kita ingin melaksanakan reformasi politik bahkan reformasi pembangunan nasional, maka kita memerlukan sumber manusia berkualitas yang ada di daaerah. Hendaknya setiap daaerah bertanggung jawab langsung terhadap pengembangan mutu sumber daya manusia yang ada diadaerahnya. Laju atau lambatnya pembangunan di daerah yang tergantung kepada mutu sumber manusianya adalah tanggung jawab masyarakat dan pemerintah daerahnya. Pendidikan dasar adalah basis dari pembangunan manusia, oleh sebab itu merupakan suatu yang mutlak apabila pengelolaannya menjadi tanggung jawab dari masyarakat di daerah dan bukan menjadi tanggung jawab birokrasi yang berada di pusat.

c. Pelatihan

Apabila pendidikan dasar sebagai basis pembangunan nasional diserahkan kepada tanggung jawab daerah maka program-program pelatihan yang dibutuhkan oleh daerah haruslah diserahkan juga kepada daerah. Derah yang persis mengetahui potensi pembangunan, kesempatan kerja, serta kemampuan-kemampuan yang dibutuhkan oleh daerah di dalam pembangunannya. Oleh sebab itu, program-program pelatihan haruslah disusun dan dilaksanakan di daerah dan bukan merupakan urusan bikrokrasi pusat. Berbagai kegagalan pembangunan kita dewasa ini antara lain 
disebabkan karena terlalu banyak campur tangan pemerintah pusat di dalam pelatihan sehingga akibatnya ialah pengangguran yang semakin lama semakin membesar sedangkan kesempatan kerja yang tersedia di daerah cukup dapat menampung tenaga-tenaga di daerah yang telah meyelesaikan pendidikan dasarnya. Bagi pelatihan-pelatihan yang lebih canggih tentunya diperlukan penanganan pemerintah pusat untuk mempersiapkan jenis-jenis dan program pelatihan yang diperlukan.

d. Pembinaan Sekolah Menengah

Apabila kita telah bertekad untuk melaksanakan wajib belajar pendidikan dara 9 tahun, maka bagaimanakah dengan pembinaan sekolah menengah kita ? dunia abad 21 sebagai dunia yang terbuka membutuhkan sumber daya manusia yang kompetitif. Sekolah menengah adalah lembagalembaga pendidikan yang mulai mempersiapkan tenaga-tenaga yang kompetitif.

Pembinaan sekolah menengah umum yang selektif berarti pula menuntut pembinaan sekolah menengah kejuruan agar supaya dapat menghasilkan tenaga-tenaga menengah terampil dan juga dapat menarik minat para siswa lulusan pendidikan dasar untuk memasukinya., pembinaan sekolah menengah umum juga harus selektif perlu mendapatkan bimbingan dari pergurun tinggi, dengan demikian pendidikan tinggi tidak melepaskan tanggung jawabnya terhadap kualitas calon mahasiswa yang akan memasuki sistem pendidikan tinggi dan sekaligus meningkatkan status pendidikan tinggi kita lebih kompetitif dalam dunia global.

e. Manajemen Pendidikan Tinggi

Salah satu bentuk reformasi yang perlu mendapatkan perhatian kita di alam pembinaan sistem pendidikan tinggi nasional ialah dualisme antara PTN dan PTS, kita semuanya mengetahui bagaimana pandangan (pemerintah) kita dewasa ini terhadap PTS yang lebih dianggap sebagai hama dan bukan sebagai partner. Antara PTN dan PTS dilihat sebagai dua sistem yang berlawanan dan saling mematikan. Sudah pada waktunya apabila disusun suatu sistem yang memungkinkan keduanya dapat saling membina dan bukan saling menyalahkan.

Fungsi Kopertis hendaknya diubah total atau dihapuskan karena yang dibina bukan hanya PTS tetapi kedua-duanya, baik PTN maupun PTS. Bagi PTN yang dianggap berkualitas diharuskan untuk membina bukan hanya PTN lainnya tetapi juga PTS yang ada didalam lingkungannya, dengan demikian, terjdilah suatu jaringan pembinaan yang saling menguntungkan antara PTN dan PTS, selanjutnya, dengan adanya kemungkinan masuknya Pendidikan Tinggi Asing maka pembinaan PTN dan PTS meminta suatu kerjasama yang positif. Dengan demikian, masuknya Pendidikan Tinggi Asing bukan merupakan suatu bahaya bagi kelangsungan hidup PTS bahkan PTN yang lemah, tetapi dapat dijadikan mitra untuk meningkatkan mutu, baik PTN maupun PTS. 
Dengan usulan beberapa kebijakan reformasi manajemen pendidikan nasional oleh Tilaar tersebut tentu kita akan melihat kesesuaian juga dengan Undang-undang Sistem Pendidikan Nasional No. 20 Tahun 2003 Pasal 64 \& 65 dan Peraturan Pemerintah No. 19 Tahun 2005 tentang Standar Nasional Pendidikan pada Bab II Pasal 2, 3 dan 4.

\section{Revolusi Pendidikan sebagai implikasi kondisi perubahan masyarakat dan perubahan tuntutan terhadap pendidikan (Pendidikan abad 21)}

Perkembangan teknomlogi yang pesat, khususnya teknologi informasi, menuntut suatu perubahan yang besar di dalam sistem pendidikan nasional. Seperti kita ketahui pendidikan kita merupakan warisan dari sistem pendidikan lama yang isinya adalah menghafal fakta-fakta tanpa arti, proses pendidikannya juga seperti menuangkan air ke dalam botol sehingga tidak ada efeknya di dalam pengembangan kemampuan untuk mencari sesuatu dan menciptakan sesuatu yang baru.

Apabila kita lihat dengan lahirnya suatu generasi baru "the net-generation", The Net-Generation atau generasi internet adalah generasi baru yang muncul pada dua dekade terakhir abad 21, generasi ini hidup dengan dunia digital atau komputer, hidup di dalam samudra informasi yang dapat diakses di mana saja dan kapan saja, dewasa ini kita mengenal suatu proses pembelajaran yang tradisional, baik yang berbentuk klasikal maupun dalam bentuk belajar sendiri. Dominasi guru sangat kental begitu pula dengan sumber sumber pelajaran yang tradisional seperti perpustakaan dan mungkin juga sudah mulai digunakan alatalat bantu belajar yang tradisional seperti radio, televisi dan alat-alat bantu lainnya. Di dalam net generation tentunya akan terjadi interaksi bukan hanya antara peserta didik dan pendidik tetapi juga peserta didik yang menghadapi dunia informasi yang terbentang tanpa batas, jika ada pendidik maka fungsinya tentu akan berbeda, pada usia yang sangat mudah sudah tentu diperlukan bimbingan pendidik dalam arti yang tradisional, namun demikian bimbingan tersebut semakin lama semakin menghilang dan berubah menjadi fasilitator yang membuka jalan bagi peserta didik untuk mengembara (roaming) secara mandiri dalam dunia informasi yang tanpa tepi. Proses belajar itu sendiri tentunya akan berubah karena tidak didikte lagi oleh para pendidik yang tradisional tetapi peserta didik semakin cepat untuk dapat berdiri sendiri. Pada fase permulaan, peserta didik akan dimbimbing untuk dapat menemukan jalannya sendiri. Di dalam proses belajar inilah akan muncul sekolah atau kampus tanpa dinding (school without walls), Menurut Don Tapscott yang dikutip Tilaar (2002:129) menggambarkan Proses Belajar Interaktif :

\section{Proses Belajar Interaktif}

\begin{tabular}{|ll|l|}
\hline \multicolumn{1}{|c|}{ Proses Belajar Mandiri } & \multicolumn{1}{c|}{ Proses Belajar Interaktif } \\
\hline $\begin{array}{l}\text { 1. } \\
\text { Guru sebagai transmitter atau } \\
\text { pembaca berita }\end{array}$ & 1. Guru sebagai fasilitator \\
\hline 2. & Sekolah sebagai penyiksa (torture) & 2. Sekolah sebagai pusat untuk \\
\hline
\end{tabular}




\begin{tabular}{|c|c|}
\hline & ebrgembira \\
\hline 3. Satu ukuran untuk semua (all size) & $\begin{array}{l}\text { 3. Sesuai dengan pelanggan } \\
\text { (costumize) }\end{array}$ \\
\hline 4. Belajar di sekolah & 4. Belajar seumur hidup \\
\hline $\begin{array}{l}\text { 5. Belajar = menyerap bahan } \\
\text { pelajaran }\end{array}$ & $\begin{array}{l}\text { 5. Belajar bagaimana belajar (learning } \\
\text { to learn) }\end{array}$ \\
\hline $\begin{array}{l}\text { 6. Guru sebagai pusat (teacher } \\
\text { center) }\end{array}$ & $\begin{array}{l}\text { 6. Peserta didik sebagai pusat (learner } \\
\text { center) }\end{array}$ \\
\hline 7. Instruksi & $\begin{array}{l}\text { 7. Konstruksi, menemukan } \\
\text { (discovery) }\end{array}$ \\
\hline $\begin{array}{l}\text { 8. Linier, berurutan (sequential } \\
\text { /serial) }\end{array}$ & 8. Belajar melalui hiper media \\
\hline
\end{tabular}

Dalam hal ini maka praktis pendidikan yang ada sekarang ini sudah tidak dapat dipergunakan lagi, sudah barang tentu mengubah suatu sistem pendidikan seperti di Indonesia bukanlah hal yang mudah. Pendidikan nasional kita tentunya bukan hanya berkaitan dengan perubahan-perubhan dalam ilmu pengetahuan dan teknologi. Namun demikian kita telah menjadi bagian dari dunia global yang dikuasai oleh teknologi, pendidikan nasional harus mempunyai "sense of crisis" untuk menghadapi tantangan ini

Abad 21 merupakan abad global. Kehidupan masyarakat berubah dengan cepat karena dunia semakin menyatu apalagi ditopang oleh kemajuan teknologi informasi dan komunikasi sehingga batas-batas masyarakat dan negara menjadi kabur. Termasuk di dalam perubahan global itu adalah profesi guru, sesuai dengan tuntutan perubahan masyarakat, profesi guru juga menuntut profesionalisme. Guru yang profesional bukan hanya sekedar alat untuk transimisi kebudayaan tetapi mentransformasikan kebudayaan itu ke arah budaya yang dinamis yang menuntut penguasaaan ilmu pengetahuan, produktivitas yang tinggi dan kualitas karya yang dapat bersaing. Guru profesional bukan lagi merupakan sosok yang berfungsi sebagai robot, tetapi merupakan dinamisator yang mengantar potensi-potensi peserta didik ke arah kreativitas.

Tugas seorang guru profesional meliputi tiga bidang utama (Tilaar, 2002: 88-89) :

1. Dalam bidang profesi. Berfungsi untuk menghajar, mendidik, melatih dan melaksanakan penelitian masalah-masalah kependidikan

2. Dalam bidang kemanusiaan. Berfungsi sebagai pengganti orang tua khususnya di dalam bidang peningkatan kemampuan intelektual peserta didik.

3. Dalam bidang kemasyarakatan. Guru berfungsi untuk memenuhi amanat dalam Pembukaan UUD 1945 yaitu ikut serta di dalam mencerdasakan kehidupan bangsa, sudah tentu tugas pokok utama dari profesi guru 
profesional ialah di dalam bidang profesinya tanpa melupakan tugastugas kemanusiaan dan kemasyarakatan lainnya.

Walaupun segala perilaku guru selalu diperhatikan masyarakat, khususnya dalam perilakunya yang berhubungan dengan profesinya karena hal ini berhubungan dengan bagaiamana pola tingkah laku guru dalam memahami, menghayati serta mengamalkan sikap kemampuan dan sikap profesionalnya, menurut Soetipto dkk (2000:43-52) ada 7 sasaran sikap profesional pola tingkah laku guru :

1. Peraturan Perundang-undangan. Guru merupakan unsur aparatur negara dan abdi negara. Karena itu mutlak perlu mengetahui kebijaksanaankebijaksanaan pemerintah dalam bidang pendidikan, sehingga dapat melakanakan ketentuan-ketentuan yang merupakan kebijaksanaan tersebut.

2. Organisasi Profesi. Guru bersama-sama memlihara dan meningkatkan mutu organisasi PGRI sebagai sarana perjuangan dan pengabdian.

3. Teman Sejawat. Kode etik guru menunjukkan betapa pentingnya hubungan yang harmonis antara sesama anggota profesi yaitu hubungan yang bersifat formal; dilakukan dalam rangka melakukan kedinasan dan hubungan kekeluargaan; hubungan persaudaraan yang dilakukan baik dalam lingkungan kerja maupun dalam rangka menunjang tercapainya keberhasilan anggota profesi

4. Anak Didik. Guru dalam mendidik seharusnya tidak hanya mengutamakan pengetahuan atau perkembangan intelektual saja, tetapi juga harus memperhatikan perkembangan seluruh pribadi peserta didik, baik jasmani, rohani, sosial maupun yang lainnya yang sesuai dengan hakikat pendidikan.

5. Tempat Kerja. Suasana kerja yang baik akan dapat meningkatkan produktivitas kerja, hal ini disadari sepenuhnya oleh guru dan guru berkewajiban menciptakan suaana yang demikian dalam lingkungannya. Untuk menciptakan susana kerja yang baik ini ada 2 hal yang harus diperhatikan yaitu (a) guru sendiri (b) hubungan guru dengan orang tua dan masyarakat sekeliling

6. Pemimpin. Sikap seorang guru terhadap pimpinan harus positif dalam pengertian harus bekerja sama dalam menyukseskan program yang sudah disepakati, baik disekolah maupun di luar sekolah.

7. Pekerjaan. Guru dituntut baik secara pribadi maupun kelompok untuk selalu meningkatkan mutu dan martabat profesinya. Guru sebagaiama juga dengan profesi lainnya, tidak mungkin dapat meningkatkan mutu dan martabat profesinya bila guru itu tidak meningkatkan atau menambah pengetahuan dan ketrampilannya, karena ilmu dan pengetahuan yang menunjang proses itu selalu berkembang sesuai dengan tuntutan jaman. 


\section{KESIMPULAN}

1. Masyarakat Indonesia sekarang berada dalam suatu era yang disebut era reformasi, di era reformasi lahir gras root revolusi sosial yang merupakan suatu korelasi nilai-nilai budaya yang ingin mewujudkan suatu masyarakat yang demokratis.

2. Perubahan kondisi masyarakat saat ini dengan runtuhnya rezim orde baru telah melahirkan suatu visi yang baru mengenai kehidupan masyarakat yang lebih sejahtera yaitu adanya pengakuan HAM.

3. Pendidikan nasional juga ikut terseok-seok dilanda krisis dan berbagai permasalahan yang terjadi di dunia pendidikan.

4. Ada 4 skenario kehidupan abad 21 yaitu :

a. Dunia tanpa batas (Borderless World)

b. Kemajuan ilmu pengetahuan dan teknologi dan implikasinya di dalam kehidupan manusia

c. Kesadaran terhadap hak dan kewajiban asai manusia (Human rights and obligations)

d. Kerjasama dan Kompetisi antar bangsa (Mega Competition Society)

5. Perubahan tuntutan terhadap pendidikan bersifat dinamis, fleksibel sehingga dapat menyerap perubahan-perubahan yang cepat perkembangan ilmu dan teknologi dengan memperhitungkan kendala-kendala pendidikan nasional yaitu sangat sentraistik, birokratis dan matinya inovasi.

6. Lahirnya suatu generasi baru "The Net-Generation" (generasi internet) harus disikapi dengan positif, sehingga masyarakat generasi ini dapat berkembang dengan optimal kemampuannya yang mengarah pada kemajuan bangsa dan negara Indonesia.

7. Profesionalitas guru harus ditingkat kompetensinya dengan penguasaan TI (Teknologi Informasi) sehingga guru tidak GATEK (Gagap Teknologi) tetapi harus dapat menggunakan teknologi dalam mendukung proses pembelajaran.

\section{DAFTAR PUSTAKA}

Ardhana W, 1997. Tantangan Pembelajaran Abad 21. Makalah.

Dimyati, Muhammad. 1988. Landasan Kependidikan. Suatu Pengantar Pemikiran Keilmuan Tentang Kegiatan Pendidikan. DEPDIKBUD: Jakarta.

Soekanto, Soerjono. 1982. Sosiologi Suatu Pengantar.

Tilaar. 2002. Membenahi Pendidikan Nasional. Rineka Cipta; Jakarta. 2005. PP No. 19 Tahun 2005. Standar Nasional Pendidikan (SNP). 2005. UU Sistem Pendidikan Nasional No. 20 Tahun 2003. 